\title{
Isolation and characterization of outer membrane proteins (OMPs) from Salmonella Gallinarum in chicken and antibiogram of the isolates
}

\author{
Asma Ul Husna ${ }^{1}$, Shabir Ahmad Mir², Rusheeba Manzoor ${ }^{1}$, Farhat Pandit ${ }^{1}$, Shakil Ah- \\ mad Wani ${ }^{1}$, Syed Alamgir ${ }^{1}$ \\ ${ }^{1}$ Veterinary Microbiology And Immunology, Sher-E-Kashmir University of Agricultural Sciences and Technology \\ of Kashmir, Srinagar- 190006 (J\&K), INDIA \\ ${ }^{2}$ Veterinary Public Health, Sher-E-Kashmir University of Agricultural Sciences and Technology of Kashmir, \\ Srinagar-190006 (J\&K), INDIA \\ *Corresponding author. E-mail: asma705@gmail.com.
}

Received: April 8, 2016; Revised received: September 9, 2016; Accepted: December 7, 2016

\begin{abstract}
Salmonella isolates should be distinguished as it may assist in tracing the source of an outbreak and monitoring trends in antimicrobial resistance associated with a particular type. The specific detection of these Salmonella serotypes is therefore extremely important in order to attribute an isolate to a previously known epidemic outbreak. The present investigation was to isolate and identify S. Gallinarum, to study variation in the profile of outer membrane proteins (OMPs) and to determine in vitro antibiogram of $S$. Gallinarum in poultry. A total of 228 faecal samples and 22 visceral samples suspected for Salmonellosis were collected, of these 15 samples $(6.0 \%)$ were found positive for $S$. Gallinarum. In the present study, rfbS gene sequence was helpful in the serotype-specific detection of S. Gallinarum giving a 187 bp product. Salmonella Gallinarum crude protein extracts determined by SDSPAGE showed migration of OMPs as several bands at approximate moleculer weights of appx. $45 \mathrm{kDa}, 55 \mathrm{kDa}, 64$ kDa, $65 \mathrm{kDa}, 74 \mathrm{kDa}, 110 \mathrm{kDa}, 120 \mathrm{kDa}, 135 \mathrm{kDa}, 150 \mathrm{kDa}, 155 \mathrm{kDa}, 200 \mathrm{kDa}$ and above $200 \mathrm{kDa}$. The study indicated a definite variation in the profile of OMPs of various Salmonella Gallinarum strains with major OMPs in the range of appx $80-100 \mathrm{kDa}$ which could be the target for vaccine production. All the isolates tested against 14 antimicrobial agents showed variable susceptibility pattern with highest resistance to nalidixic acid, ampicillin and sulphadiazine and sensitivity to chloramphenicol, gentamicin and enrofloxacin.
\end{abstract}

Keywords: Antibiogram, Outer membrane protein (OMP), PCR, Salmonella Gallinarum, SDS-PAGE

\section{INTRODUCTION}

Salmonella are well-known pathogens, highly adaptive and potentially pathogenic for humans and/or animals. Salmonella express flagella, polysaccharide and capsular antigens which determine strain pathogenicity and therefore variation of these antigens has formed the basis for Salmonella serotyping. Salmonella Gallinarum is the only serotype in the Kauffmann-White scheme that does not express any flagella antigen and is therefore non-motile (Sonne-Hansen and Jenabian, 2005). Salmonella Gallinarum is the causative agent of fowl typhoid, a severe systemic disease of chicken and other galliforme birds (Gast, 1997). Clinical signs of fowl typhoid in chicken include anorexia, diarrhoea, dehydration, and decreased egg production(Christensen et al., 1992a,b). A rapid polymerase chain reaction (PCR) method based on the detection of $r f b S$ gene for the serotype-specific detection of $S$. Gallinarum and its differentiation from the closely related $S$. Pullorum has been developed which encodes paratose synthetase. This gene was found to be uniquely present in the serotypes belonging to Salmonella serogroup D (Verma and
Reeves, 1989; Liu et al., 1991).

Since proteins are better antigens than carbohydrates, the outer membrane proteins (OMPs) of Salmonella have been considered possible candidates for conferring protection against fowl typhoid. OMPs interface the cell with the environment, thus represent important virulence factors with a significant role in the pathobiology of gram-negative bacteria and bacterial adaptation. Induction of protective immunity by such protein antigens has been demonstrated by Plant et al. (1978). The use of outer membrane proteins (OMPs) from Salmonella Gallinarum was examined for its protective ability in a vaccine preparation (Bouzoubaa et al., 1987; Bouzoubaa et al., 1989; Prakash et al., 2005; Sahar et al., 2009).

Antimicrobial resistance is the capacity of bacteria to survive exposure to a defined concentration of an antimicrobial substance. Antimicrobial resistance is one of the major health problems in human and veterinary medicine and has tremendous economic consequences that lead to strong scientific and public-health efforts to improve the situation. Therapeutic regime is important 
for monitoring drug resistance pattern, and is important to devise a comprehensive chemoprophylactic and chemotherapeutic drug schedule within a geographical area (Murugkar et al., 2005). The major selective pressures on Salmonella arise from the overuse of antimicrobials for prophylaxis and therapy. In particular, the wide use of mixtures of antimicrobials, antimicrobials mixed into animal feeds and therapy without diagnosis leads to a long-lasting, strong selective pressure in animal husbandry and on Salmonella in intensive production units.

The main objectives of the study were to isolate and identify $S$. Gallinarum. to determine the variation in the profile of Outer Membrane Proteins (OMPs) of $S$. Gallinarum and to study the in vitro antibiogram of $S$. Gallinarum isolates from chicken.

\section{MATERIALS AND METHODS}

Sampling and isolation: A total of 250 samples consisting of 228 faecal samples from live diseased birds and 22 visceral samples were collected randomly from private and government poultry farms. Samples were directly inoculated in Tetrathionate broth (TTB) and incubated at $42^{\circ} \mathrm{C}$ for $48 \mathrm{hrs}$ for primary enrichment. Suspected colonies were further purified by subculture and transferred onto nutrient agar slants. Characterization and preliminary identification of suspected $S$. Gallinarum colonies was made on the basis of morphological, cultural and biochemical characteristics (Holt et al., 1994).

Molecular detection by polymerase chain reaction: Salmonella Gallinarum isolates were identified by targeting $r f b S$ gene using a PCR method for serotypespecific detection of $S$. Gallinarum as described by Shah et al. (2005). Extraction of bacterial DNA was done by boiling method. A primer set consisting of forward primer, $r f b \mathrm{~S} F\left(5^{\prime}\right.$ GTA TGG TTA TTA GAC GTT GTT $3^{\prime}$ ) and reverse primer, $r f b S$ R (5' TAT TCA CGA ATT GAT ATA CTC 3') were used in the present study as designed by Shah et al. (2005). All PCR assays were carried out in sterile $0.2 \mathrm{ml}$ PCR tubes. Each PCR mixture of $25 \mu 1$ consisted of $2.5 \mu \mathrm{l}$ of $10 \mathrm{X}$ buffer, $1.5 \mathrm{mM} \mathrm{MgCl}_{2}, 0.2 \mathrm{mM}$ dNTP mix, $0.5 \mu 1$ primers forward and reverse (20 pmol each), template DNA (about $100 \mathrm{ng}$ ), $2.5 \mathrm{U}$ of Taq DNA polymerase and nuclease free water $(17.3 \mu \mathrm{l})$. The cycling parameters included an initial denaturation of $94^{\circ} \mathrm{C}$ for $5 \mathrm{~min}$, followed by 33 cycles of denaturation at $94^{\circ} \mathrm{C}$ for 1 min, annealing at $60^{\circ} \mathrm{C}$ for $1 \mathrm{~min}$, extension at $72^{\circ} \mathrm{C}$ for $1 \mathrm{~min}$ and the final extension was at $72^{\circ} \mathrm{C}$ for 5 min. The amplification product was analyzed by submarine gel electrophoresis and calibrated by a $100 \mathrm{bp}$ DNA marker (MBI Fermentas, USA). The products were analyzed using Uvitec, Genei transilluminator and then photographed under UV gel documentation system (Ultracam Digital Imaging, Ultra Lum. Inc, Claremont, CA).

Isolation and purification of outer membrane proteins: Salmonella Gallinarum outer membrane proteins were isolated by the method of Choi et al. (1991) with modifications. The isolates were inoculated in Luria Bertaini broth and the inoculated broth was kept in a shaking incubator at $37^{\circ} \mathrm{C}$ for $16 \mathrm{hrs}, 200$ rpm. The samples were centrifuged at $8000 \mathrm{rpm}$ for 20 mins at $4^{\circ} \mathrm{C}$. The supernatant was discarded and the cell pellets were used for outer membrane protein isolation. The cell pellets were stored at -40 to $-80^{\circ} \mathrm{C}$. The cell pellets were dispersed in $10 \mathrm{ml}$ of $10 \mathrm{mM}$ HEPES (pH 7.4) and vortexed properly for 5 mins. The pellets were sonicated at an amplitude of $30 \%$ with $59 \mathrm{sec}$ on ice. The samples were further centrifuged at $17,000 \mathrm{~g}$ for $20 \mathrm{mins}$ at $4^{\circ} \mathrm{C}$ to remove the cell debris. The supernatants were subjected to ultracentrifugation at $2,30,000 \mathrm{~g}$ for $70 \mathrm{mins}$ at $4^{\circ} \mathrm{C}$ to pellet the membrane fraction. The pellets were incubated in $10 \mathrm{ml}$ of $2 \%$ sodium sarkosynate in HEPES overnight at room temperature. The samples were again subjected to ultra-centrifugation at $1,25,000 \mathrm{~g}$ for $110 \mathrm{mins}$ at $4^{\circ} \mathrm{C}$. The supernatants were discarded and the pellets were dissolved in $200 \mu \mathrm{l}$ of PBS. These were used as outer membrane proteins.

SDS-PAGE: The variation in the outer membrane proteins (OMPs) was analysed by sodium dodecyl sulfate polyacrylamide gel electrophoresis (SDS-PAGE) using discontinuous buffer system (Laemmli and Laemmli, 1970). Following electrophoresis, the gel was stained with Comassie blue R250 stain, allowing visualization of the separated proteins. A molecular weight marker of known molecular weight was run in a separate lane in the gel, in order to calibrate the gel. The staining was carried overnight in a rocker. After staining, the gel was destained in a destaining solution of acetic acid and methanol. Protein bands were visualized and photographed by Gel Documentation System.

Antibiotic sensitivity test: In vitro antibiotic sensitivity pattern of the Salmonella Gallinarum isolates to various antimicrobial agents was determined by disc diffusion method (Bauer et al., 1966). A predetermined battery of antimicrobial discs was used in the present study. The interpretation of the isolates as sensitive, intermediate, and resistant was done as per manufacturer's instructions.

\section{RESULTS}

Isolation and detection of Salmonella Gallinarum: Out of 250 samples, 15 samples $(6.0 \%)$ were found positive for $S$. Gallinarum by conventional isolation and identification methods in the laboratory and by polymerase chain reaction (Table 1). Positive samples generated an amplicon of $187 \mathrm{bp}$ on the amplification of $r f b S$ gene (Fig.1).

OMP profile of Salmonella Gallinarum isolates: Five representative samples were selected from the 15 isolates of Salmonella Gallinarum for the OMP extraction and five different profiles were observed on the extraction of OMP. On comparing OMP profiles of vari- 
Table 1. Number of samples positive for Salmonella Gallinarum.

\begin{tabular}{|c|c|c|c|c|c|c|c|c|}
\hline \multirow[t]{2}{*}{ S. No. } & \multirow{2}{*}{$\begin{array}{l}\text { Samples taken } \\
\text { from }\end{array}$} & \multicolumn{2}{|c|}{ Samples } & \multirow{2}{*}{$\begin{array}{l}\text { Total } \\
\text { samples }\end{array}$} & \multicolumn{2}{|c|}{$\begin{array}{c}\text { Samples positive for } \\
\text { Salmonella Gallinarum }\end{array}$} & \multirow{2}{*}{$\begin{array}{l}\text { Total positive } \\
\text {-samples }\end{array}$} & \multirow{2}{*}{ Percentage } \\
\hline & & FS & VS & & FS & VS & & \\
\hline 1. & Local Poultry Farms & 180 & 20 & 200 & 11 & 2 & 13 & 6.5 \\
\hline 2. & Govt. Poultry Farms & 48 & 2 & 50 & 1 & 1 & 2 & 4 \\
\hline
\end{tabular}

FS - Faecal sample, VS- Visceral sample

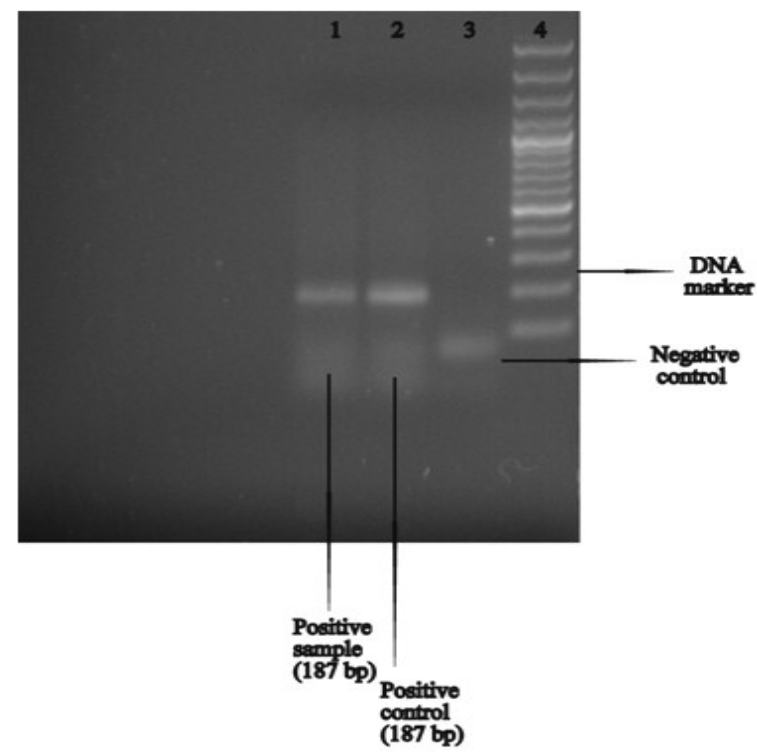

Fig. 1. PCR amplification of rfbS gene from Salmonella Gallinarum isolates.Lane 1: Salmonella Gallinarum positive sample (187 bp);Lane 2: Salmonella Gallinarum Positive control (187 bp); Lane 3: Negative control; Lane 4: DNA marker.

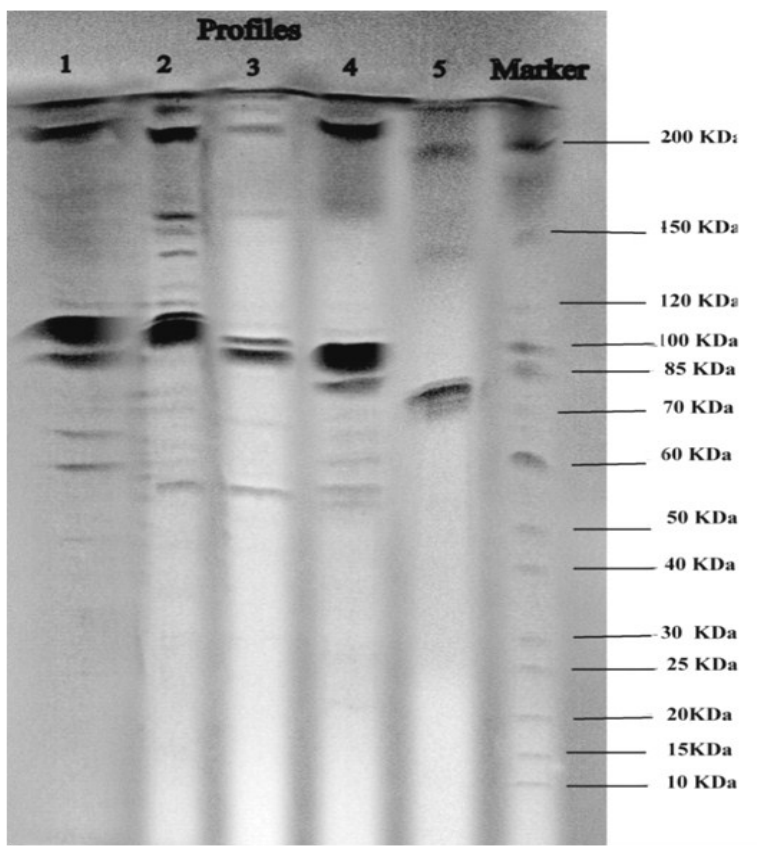

Fig. 2. SDS-PAGE showing profile variations in OMPs of Salmonella Gallinarum.

Table 2. In vitro antibiotic sensitivity pattern of Salmonella Gallinarum isolates.

\begin{tabular}{|c|c|c|c|c|c|c|c|c|c|c|c|c|c|c|c|}
\hline $\begin{array}{l}\text { Sample } \\
\text { No. }\end{array}$ & Serotype & C & G & Ak & $\mathbf{S}$ & $\mathbf{C i}$ & $\mathbf{A}$ & Sz & $\mathbf{E x}$ & Ac & Cs & $\mathrm{Na}$ & $\mathbf{N}$ & $\mathbf{N x}$ & $\mathbf{T}$ \\
\hline 1. & S. Gallinarum & $\mathrm{S}$ & $\mathrm{S}$ & $\mathrm{S}$ & $\mathrm{S}$ & $\mathrm{S}$ & $\mathrm{R}$ & $\mathrm{R}$ & $\mathrm{S}$ & I & $\mathrm{R}$ & $\mathrm{R}$ & I & $\mathrm{S}$ & I \\
\hline 2. & S. Gallinarum & $\mathrm{S}$ & $\mathrm{S}$ & I & I & $\mathrm{S}$ & $\mathrm{R}$ & $\mathrm{R}$ & $\mathrm{S}$ & $\mathrm{S}$ & I & $\mathrm{R}$ & I & $\mathrm{S}$ & $\mathrm{S}$ \\
\hline 3. & S. Gallinarum & $\mathrm{S}$ & $\mathrm{S}$ & I & $\mathrm{R}$ & $\mathrm{R}$ & $\mathrm{R}$ & $\mathrm{R}$ & $\mathrm{S}$ & $\mathrm{S}$ & $\mathrm{S}$ & $\mathrm{R}$ & I & I & I \\
\hline 4. & S. Gallinarum & S & $\mathrm{S}$ & I & I & I & $\mathrm{R}$ & $\mathrm{R}$ & $\mathrm{S}$ & $\mathrm{S}$ & I & $\mathrm{R}$ & $\mathrm{S}$ & $\mathrm{R}$ & I \\
\hline 5. & S. Gallinarum & S & I & $\mathrm{S}$ & $\mathrm{S}$ & I & $\mathrm{S}$ & $\mathrm{S}$ & I & I & $\mathrm{R}$ & I & I & I & I \\
\hline 6. & S. Gallinarum & I & $\mathrm{S}$ & $\mathrm{S}$ & $\mathrm{R}$ & I & I & $\mathrm{R}$ & $\mathrm{S}$ & I & $\mathrm{S}$ & $\mathrm{R}$ & I & $\mathrm{R}$ & $\mathrm{S}$ \\
\hline 7. & S. Gallinarum & $\mathrm{S}$ & $\mathrm{S}$ & $\mathrm{S}$ & I & $\mathrm{R}$ & $\mathrm{R}$ & $\mathrm{R}$ & I & $\mathrm{S}$ & I & $\mathrm{R}$ & I & I & $\mathrm{S}$ \\
\hline 8. & S. Gallinarum & I & $\mathrm{R}$ & $\mathrm{R}$ & I & $\mathrm{R}$ & $\mathrm{R}$ & $\mathrm{R}$ & $\mathrm{S}$ & I & $\mathrm{R}$ & $\mathrm{R}$ & $\mathrm{R}$ & $\mathrm{S}$ & I \\
\hline 9. & S. Gallinarum & $\mathrm{S}$ & I & I & $\mathrm{S}$ & I & $\mathrm{R}$ & $\mathrm{S}$ & $\mathrm{S}$ & $\mathrm{S}$ & $\mathrm{S}$ & $\mathrm{R}$ & I & $\mathrm{R}$ & $\mathrm{S}$ \\
\hline 10. & S. Gallinarum & S & $\mathrm{S}$ & $\mathrm{R}$ & $\mathrm{S}$ & $\mathrm{S}$ & $\mathrm{S}$ & $\mathrm{R}$ & $\mathrm{S}$ & I & $\mathrm{R}$ & I & $\mathrm{R}$ & $\mathrm{S}$ & $\mathrm{S}$ \\
\hline 11. & S. Gallinarum & I & $\mathrm{S}$ & I & $\mathrm{R}$ & I & $\mathrm{R}$ & $\mathrm{S}$ & I & $\mathrm{S}$ & I & $\mathrm{R}$ & I & $\mathrm{S}$ & I \\
\hline 12. & S. Gallinarum & S & $\mathrm{S}$ & $\mathrm{R}$ & $\mathrm{S}$ & $\mathrm{R}$ & $\mathrm{R}$ & $\mathrm{R}$ & I & I & $\mathrm{R}$ & $\mathrm{R}$ & $\mathrm{R}$ & $\mathrm{S}$ & $\mathrm{S}$ \\
\hline 13. & S. Gallinarum & $\mathrm{S}$ & $\mathrm{S}$ & $\mathrm{S}$ & $\mathrm{S}$ & $\mathrm{R}$ & I & $\mathrm{S}$ & $\mathrm{S}$ & $\mathrm{S}$ & $\mathrm{R}$ & $\mathrm{R}$ & I & I & I \\
\hline 14. & S. Gallinarum & $\mathrm{S}$ & $\mathrm{S}$ & $\mathrm{S}$ & $\mathrm{R}$ & $\mathrm{S}$ & I & $\mathrm{R}$ & I & $\mathrm{S}$ & $\mathrm{R}$ & $\mathrm{R}$ & $\mathrm{R}$ & I & $\mathrm{R}$ \\
\hline 15. & S. Gallinarum & S & $\mathrm{R}$ & $\mathrm{R}$ & $\mathrm{S}$ & $\mathrm{S}$ & $\mathrm{R}$ & $\mathrm{S}$ & $\mathrm{S}$ & I & $\mathrm{R}$ & $\mathrm{R}$ & I & $\mathrm{S}$ & $\mathrm{S}$ \\
\hline
\end{tabular}

$\mathrm{S}=$ Sensitive, $\mathrm{R}=$ Resistant $\mathrm{I}=$ Intermediate, $\mathrm{C}=$ Chloramphenicol, $\mathrm{G}=$ Gentamicin, $\mathrm{Ak}=$ Amikacin, $\mathrm{S}=\mathrm{Streptomycin}, \mathrm{Ci}=$

Ceftriaxone, $\mathrm{A}=$ Ampicillin, $\mathrm{Sz}=$ Sulphadiazine $\mathrm{Ex}=$ Enrofloxacin, $\mathrm{Ac}=$ Amoxicillin-Clavulanic acid $, \mathrm{Cs}=\mathrm{Cefoperazone}, \mathrm{Na}$

$=$ Nalidixic acid, $\mathrm{N}=$ Neomycin, $\mathrm{Nx}=$ Norfloxacin, $\mathrm{T}=$ Tetracycline

ous Salmonella Gallinarum isolates it was observed that the major OMPs were in the range of appx. 80-100 kDa. (Fig. 2).

Profile 1 of OMPs exhibited the major bands of approximately $100 \mathrm{kDa}, 110 \mathrm{kDa}$. The minor bands in- cluded $45 \mathrm{kDa}, 60 \mathrm{kDa}, 65 \mathrm{kDa}, 70 \mathrm{kDa}, 120 \mathrm{kDa}$. Profile 2 of OMPs exhibited the major bands of approximately $110 \mathrm{kDa}, 200 \mathrm{kDa}$. The minor bands included $55 \mathrm{kDa}, 64 \mathrm{kDa}, 65 \mathrm{kDa}, 74 \mathrm{kDa}, 120 \mathrm{kDa}, 135$ $\mathrm{kDa}, 150 \mathrm{kDa}, 155 \mathrm{kDa}$ and above $200 \mathrm{kDa}$. Profile 3 
of OMPs exhibited the major bands of approximately $100 \mathrm{kDa}$ and $110 \mathrm{kDa}$. The minor bands included 55 $\mathrm{kDa}, 70 \mathrm{kDa}, 160 \mathrm{kDa}, 200 \mathrm{kDa}$ and above $200 \mathrm{kDa}$. Profile 4 of OMPs exhibited the major bands of approximately $85 \mathrm{kDa}, 100 \mathrm{kDa}, 200 \mathrm{kDa}$. The minor bands included $55 \mathrm{kDa}, 57 \mathrm{kDa}, 60 \mathrm{kDa}, 68 \mathrm{kDa}, 70$ $\mathrm{kDa}$ and $105 \mathrm{kDa}$. Profile 5 of OMPs exhibited the major bands of approximately $80 \mathrm{kDa}$ and $200 \mathrm{kDa}$. The minor bands included $70 \mathrm{kDa}$ and $140 \mathrm{kDa}$.

Invitro antibiotic sensitivity pattern of Salmonella Gallinarum isolates: For the antibiotic sensitivity test a total of 15 isolates of $S$. Gallinarum were tested against 14 antimicrobials and the results obtained were recorded (Table 2). Almost all $S$. Gallinarum isolates were resistant to nalidixic acid, ampicillin and sulphadiazine and were sensitive to chloramphenicol, gentamicin and enrofloxacin.

\section{DISCUSSION}

Salmonella infection is serious medical and veterinary problem world-wide causing great concern in the food industry. Two avian-adapted serovars $S$. Gallinarum and $S$. Pullorum are causative organisms of fowl typhoid and pullorum disease respectively (Lee et al., 2003). Fowl typhoid ( $S$. Gallinarum) and Pullorum disease ( $S$. Pullorum) remain to cause economic losses throughout the globe (Mastroeni and Menager, 2003) due to heavy mortality in poultry. Isolation of Salmonella from poultry and poultry products is higher as compared to the isolation from other animal species (Davies and Breslin, 2003; Myint, 2004). In the present study, isolation of Salmonella from poultry tissue samples (visceral organs) was $3 / 22$ (13.63\%) (Table 1). This is higher than the findings of Menghistu et al. (2011) who reported $2.7 \%$ isolation of Salmonella from poultry tissues. This variation may be associated with various factors such as season of the study, geographic location and hygienic conditions in the farm.

$S$. Gallinarum and $S$. Pullorum are non-motile, host adapted avian pathogens belonging to Salmonella serogroup D (Pomeroy and Nagaraja, 1991). Serotypes Gallinarum (SG), Pullorum (SP) and Enteritidis (SE) are very similar from the point of view of their antigenic structure, however, they are responsible for distinctly different diseases in chicken (Shivaprasad, 2000; Gast, 1997), this makes specific detection of these Salmonella serotypes extremely important from epidemiological and preventive perspectives. Polymerase chain reaction (PCR) can particularly be a useful tool to provide rapid and definitive detection of these avian Salmonella serotypes (Shah et al., 2005). Interestingly, $r f b S$ gene encoding paratose synthetase (a final step in the biosynthetic pathway of O-side chain sugars) was found to be uniquely present in the serotypes belonging to Salmonella serogroup D (Verma and Reeves, 1989; Liu et al., 1991; Luk et al., 1993).

The primers used in this study proved to be specific for the PCR detection of all $S$. Gallinarum isolates identified by conventional tests and gave positive bands with PCR detection. A unique amplification product of 187 bp pairs was obtained with $S$. Gallinarum specific isolates which corresponded with the findings of Shah et al. (2005) in South Korea and Al- Ledani et al. (2014). Also a same study was carried out by Desai et al. (2005) for the serotype-specific detection of Pullorum and its differentiation from the closely related Gallinarum using a rapid allele-specific polymerase chain reaction (PCR) method based on the nucleotide polymorphism in $r f b S$ gene sequence. This observation also confirms the preliminary findings made by Park et al. (2001) in Korea for differential diagnosis of $S$. Gallinarum and $S$. Pullorum using PCR-RFLP and ALIedani et al. (2014) using $r f b s g$ and $r f b s p$ genes amplification of $S$. gallinarum and $S$. pullorum .

Salmonella possess surface structures that can induce protective humoral and cellular immune responses following experimental infection in poultry (Liu et al., 2001; Timms et al., 1994). These components include LPS, OMPs, fimbriae and flagellin. The OMPs of gram-negative bacteria are immunologically important because of their accessibility to the host defense system. There are some strains which vaccines do not cover, hence for these bacteria the novel immunogenic targets are being researched for designing new vaccines. The heterogenicty may serve as a target for vaccine production.

Heterogenicity in outer membrane protein profile indicates that there could be definite strain variation in Salmonella Gallinarum isolates. Heterogenicity may be due to variation in habitat, host range and virulence. However, some similarity in OMP profile was observed for some isolates of Salmonella Gallinarum and the common OMPs of different Salmonella Gallinarum isolates exhibited major bands in the region of nearly 80- $100 \mathrm{kDa}$, which could be the target for vaccine production (Prakash et al., 2005). The OMP electrophoretic analysis of the Salmonella Gallinarum showed that the isolates shared many protein bands. The intense protein bands which occupied the range from 80 to $120 \mathrm{kDa}$ constituted the majority of the Salmonella Gallinarum OMP bands.

Salmonella Gallinarum crude protein extracts determined by SDS-PAGE showed migration of OMPs as several bands at approximate moleculer weights of 45 $\mathrm{kDa}, 55 \mathrm{kDa}, 64 \mathrm{kDa}, 65 \mathrm{kDa}, 74 \mathrm{kDa}, 110 \mathrm{kDa}, 120$ $\mathrm{kDa}, 135 \mathrm{kDa}, 150 \mathrm{kDa}, 155 \mathrm{kDa}, 200 \mathrm{kDa}$ and above $200 \mathrm{kDa}$ which nearly corresponds with the findings of Lee et al. (2005).

Presently, antimicrobial therapy is one of the primary control measures for reducing morbidity and mortality due to pathogens including Salmonella organisms. However, there is need for judicious use of antimicrobials for effective treatment and to avoid the development of drug resistance among the clinical bacterial 
isolates. This can be achieved by prior determination of in vitro sensitivity test of the clinical bacterial isolates. In the present study, all the Salmonella Gallinarum isolates were tested against 14 antimicrobial agents. Almost all $S$. Gallinarum isolates were resistant to nalidixic acid, ampicillin and sulphadiazine but were sensitive to chloramphenicol, gentamicin and enrofloxacin. This multi drug resistance of the isolates might be due to indiscriminate use of antibacterials in clinical practice and also due to their use as feed additives. These resistance levels are comparable to those previously reported for Salmonella Gallinarum isolates by Mir et al. (2010) in which $S$. Gallinarum were resistant to cefpodoxime, sulphadiazine and nalidixic acid. Carraminana et al. (2004) also reported that Salmonella isolates from a poultry slaughterhouse in Zaragoza (Spain) showed resistance to sulphadiazine and AlZenki et al. (2007) reported resistance of Salmonella isolates to ampicillin and nalidixic acid in poultry farm and processing plant in Kuwait which is in conformation with our findings.

\section{Conclusion}

It was concluded that 15 samples $(6.0 \%)$ were found positive for $S$. Gallinarum by conventional isolation and identification methods and $r f b S$ gene sequence was helpful in the serotype-specific detection of $S$. Gallinarum giving an amplification product of $187 \mathrm{bp}$. SDS-PAGE showed migration of OMPs as several bands at approximate moleculer weights of appx. 45 $\mathrm{kDa}, 55 \mathrm{kDa}, 64 \mathrm{kDa}, 65 \mathrm{kDa}, 74 \mathrm{kDa}, 110 \mathrm{kDa}, 120$ $\mathrm{kDa}, 135 \mathrm{kDa}, 150 \mathrm{kDa}, 155 \mathrm{kDa}, 200 \mathrm{kDa}$ and above $200 \mathrm{kDa}$. Some similarity was observed in some isolates of $S$. Gallinarum, showing common bands in the region of nearly $80-100 \mathrm{kDa}$ and the major protein bands occupied the range approximately from 85 to $120 \mathrm{kDa}$ constituting the majority of the $S$. Gallinarum OMP bands. Variation in the outer membrane proteins may be due to strain variation which may serve as a potential target for vaccine production and may also indicate various genetic mutations in $S$. Gallinarum strains.

Almost all $S$. Gallinarum isolates were resistant to nalidixic acid, ampicillin and sulphadiazine but were sensitive to chloramphenicol, gentamicin and enrofloxacin. So farmers, veterinarians, slaughter and food manufacturing facilities etc should go for judicious use of antibiotics in the animal industry and implement biosecurity measures to address problem of dissemination of antimicrobial resistance in Salmonella in addition to other infectious agents.

\section{REFERENCES}

AL-Iedani, A.A., Mohammed, H.K., and Nael, M.O. (2014). Isolation and identification of Salmonella spp. from poultry farms by using different techniques and evaluation of their antimicrobial susceptibilities. Bas. J. Vet. Res., 1 (1):246-259
Al-Zenki, S., Al-Nasser, A., Al-Safar, A., Alomirah, H., AlHaddad, A., Hendriksen, R.S., Aarestrup, F.M., Aarestrup. (2007). Prevalence and antibiotic resistance of Salmonella isolated from a poultry farm and processing plant environment in the State of Kuwait. Foodborne Pathog Dis., 4(3): 367-373

Bauer, A.W., Bauer, Kirby, W.M., Kirby, Sherris, J.C., Sherris and Turck, M., Turck. (1966). Antibiotic susceptibility testing by a standardized single disk method. American Journal of Clinical Pathology, 45(4): 493496

Bouzoubaa, K. Bouzoubaa, Nagaraja, K.V. Nagaraja, Kabbaj, F.Z. Kabbaj, Newman, J.A. Newman and Pomeroy, B.S. Pomeroy (1989). Feasibility of using proteins from Salmonella Gallinarum vs. 9R live vaccine for the prevention of fowl typhoid in chickens. Avian. Dis., 33: 385-391

Bouzoubaa, K. Bouzoubaa, Nagaraja, K.V. Nagaraja, Newman, J.A. Newman and Pomeroy, B.S. Pomeroy (1987). Use of membrane proteins from Salmonella Gallinarum for prevention of fowl typhoid infection in chickens. Avian. Dis., 31: 699-704

Carraminana, J.J. Carraminana, Rota, C. Rota, Agustín, I. Agustín and Herrera, A. Herrera (2004). High prevalence of multiple resistance to antibiotics in Salmonella serovars isolated from a poultry slaughterhouse in Spain. Veterinary Microbiology, 104: 133-139

Choi-Kim, K. Choi-Kim, Maheswaran, S.K. Maheswaran, Felice, L.J. Felice and Molitor, T.W. Molitor (1991). Relationship between the iron regulated outer membrane proteins and the outer membrane proteins of in vivo grown Pasteurella multocida. Veterinary Microbiology, 28(1): 75-92

Christensen, J.P. Christensen, Olsen, J.E. Olsen and Bisgaard, M. Bisgaard. (1992a). Characterization of Salmonella enterica serotype gallinarum biotypes gallinarum and pullorum by plasmid profiling and biochemical analysis. Avian Pathology, 21: 461 -470

Christensen, J.P. Christensen, Olsen, J.E. Olsen and Bisgaard, M. Bisgaard (1992b). Ribotypes of Salmonella enterica serovar Gallinarum biovars Gallinarum and Pullorum. Avian Pathology, 22: 725-738

Davies, R.H. Davies and Breslin, M. Breslin (2003). Observations on Salmonella contamination of commercial laying farms before and after cleaning and disinfection. Veterinary Records, 152: 283-287

Desai, A.R., Shah, D.H., Shringi, S., Lee, M.J., Li, Y. H., Cho, M.R., Park, J.H., Eo, S.K, Lee, J.H, Chae, J. S. (2005). An allele-specific PCR assay for the rapid and serotype-specific detection of Salmonella Pullorum. Avian Dis., 49(4): 558-61

Gast, R.K. Gast (1997). Salmonella infections in Diseases of Poultry. Iowa State University Press, Ames, pp. 81-121.

Holt, J.G Holt, Krieg, N.R. Krieg, Sneath, P.H.A. Sneath and Williams, S.T. Williams. (1994). Bergey's manual of determinative bacteriology, 9th Ed. Lippincott, Williams \& Wilkins, Baltimore, Maryland.

Laemmli, U.K. Laemmli. (1970). Cleavage of structural proteins during the assembly of the head of bacteriophage T4. Nature, 227(5259): 680-685

Lee, Y.J. Lee, Kim, K.S. Kim, Kwon, Y.K. Kwon and Tak, R.B. Tak. (2003). Biochemical characteristics and antimicrobials susceptibility of Salmonella Gallinarum 
isolated in Korea. Journal of Veterinary Sciences, 4(2): 161-166

Lee, Y.S. Lee, Chol, K.S. Chol, Kim, M.C. Kim, Han, J.C. Han, Park, J.H. Park, Shah, D.H. Shah and Chae, J.S. Chae. (2005). Purification of outer membrane protein (OMP C) from Salmonella Gallinarum for characterization of its immunogenicity. Indian Journal of Animal Sciences, 75(2): 164-167

Liu, D., Liu, Verma N.K., Verma, Romana, L.K. Ro,mana and Reeves, P.R. Reeves. (1991). Completing the sequence of the $r f b$ region of Salmonella serovars typhi (group D) and paratyphi (group A): relationship with group B. Journal of Bacteriology, 173: 4814-4819

Liu, W. Liu, Yang, Y. Yang, Chung, N. Chung and Kwang, J. Kwang. (2001). Induction of humoral immune response and protective immunity in chickens against Salmonella enteritidis after a single dose of killed bacterium loaded microspheres. Avian Dis., 45: 797-806

Luk, J.M.C. Luk, Kongmuang, U. Kongmuang, Reeves, P.R. Reeves and Lindberg, A.A. Lindberg. (1993). Selective amplification of abequose and paratose synthetase $(r f b)$ by polymerase chain reaction for identification of $\mathrm{Sal}$ monella major serogroups (A, B, C2, and D). Journal of Clinical Microbiology, 31: 2118-2123

Mastroeni, P. Mastroeni and Menager, N. Menager. (2003). Development of acquired immunity to Salmonella. Journal of Medical Microbiology, 52 : 453-n. mising

Menghistu, H.T. Menghistu, Rathore, R. Rathore, Dhama, K. Dhama and Agarwal, R.K. Agarwal (2011). Isolation, Identification and Polymerase Chain Reaction (PCR) Detection of Salmonella Species from Field Materials of Poultry Origin. International Journal of Microbiological Research, 2(2) : 135-142

Menghistu, H.T. Menghistu, Rathore, R. Rathore, Dhama, K. Dhama and Agarwal, R.K. Agarwal (2011). Isolation, identification and polymerase chain reaction (PCR) detection of salmonella species from field materials of poultry origin. International Journal of Microbiological Research, 2(2): 135-142

Mir, I.A. Mir, Wani, S.A. Wani, Hussain, I. Hussain, Qureshi, S.D. Qureshi, Bhat, M.A. Bhat and Nishikawa, Y. Nishikawa. (2010). Molecular epidemiology and in vitro antimicrobial susceptibility of Salmonella isolated from poultry in Kashmir. Rev. Sci. Tech. Off. Int. Epiz., 29(3): 677-686

Murugkar, H.V. Murugkar, Rahman, H. Rahman, Kumar, A. Kumar and Bhattacharya, D. Bhattacharya. (2005). Isolation, phage typing and antibiogram of Salmonella from man and animals in northeastern
India. Indian Journal of Medical Research, 122: 237-242

Myint, M.S. Myint. (2004). Epidemiology of Salmonella contamination of poultry products; Knowledge gaps in the farm to store products, M.Sc. thesis, Maryland Univ., Faculty of the Graduate School. 459

Park, M.K. Park, Choi, K.S. Choi, Kim, M.C. Kim and Chae, J.S. Chae (2001). Differential diagnosis of Salmonella Gallinarum and $S$. Pullorum using PCR-RFLP. Journal of. Veterinary Sciences, 2: 213-219

Plant, J. Plant, Glynn, A.A. Glynn and Wilson, B.M. Wilson B.M. (1978). Protective effects of a supernatant factor from Salmonella Typhimurium on Salmonella Typhimurium infection of inbred mice. Infect. Immun., 22: 125-131

Pomeroy, B.S. Pomeroy and Nagaraja, K.V. Nagaraja (1991). Fowl typhoid. Diseases of Poultry, 9th edition. Iowa State University press, Ames, IA, pp. 87-99

Prakash, B., Suryanarayana, T., Muniyappa, L. and Krishnappa, G. (2005) . Evaluation of salmonella gallinarum outer membrane protein based enzyme linked immunosorbent assay for detecting antibodies in vaccinated and infected chicken. International Journal of Poultry Science, 4 (4): 222-227

Sahar, A., Zoo El-Fakar and Nagwa, Rabie, S. (2009). Immunogenic properties of outer membrane proteins of salmonella in chicken. Global Veterinaria, 3 (2): 75-79

Shah, D.H. Shah, Park, J.H. Park, Cho, M.R. Cho, Kim M.C. Kim and Chae J.S. Chae. (2005). Allele specific PCR method based on $r f b S$ sequence for distinguishing Salmonella Gallinarum from Salmonella Pullorum: serotype-specific $r f b S$ sequence polymorphism. Journal of Microbiological Methods, 60: 169-177

Shivaprasad, H.L. Shivaprasad. (2000). Fowl typhoid and pullorum disease. Review in Scientific Technologies (Off. Inter. Des Epi.), 19: 405-424

Sonne-Hansen, J. Sonne-Hansen and Jenabian, S.M. Jenabian. (2005). Molecular serotyping of Salmonella: Identification of the phase $1 \mathrm{H}$ antigen based on partial sequencing of the fliC gene. Acta Pathologica, Microbiologica et Immunologica Scandinavica, 113: 340-348

Timms, L.M. Timms, Marshall, R.N. Marshall and Breslin, M.F. Breslin. (1994). Laboratory and field trial assessment of protection given by a Salmonella enteritidis PT4 inactivated, adjuvant vaccine, $B r$. Vet. J., 150: 93-102

Verma, N. Verma and Reeves, P.R. Reeves. (1989). Identification and sequence of $r f b \mathrm{~S}$ and $r f b \mathrm{E}$, which determine antigenic specificity of group A and group D Salmonellae. Journal of Bacteriology, 171: 5694-5701 